\title{
Ethics of Hippocratic Thought in GPA: Ethics for a New Formula
}

\author{
Bernard Troude* \\ Associate Researcher of CEAQ, International Academy of Medical Ethics and Correspondent of the International Academy of Medicine \\ and Medical Ethics. Paris. (SEFFEM)
}

Received: April 20, 2018; Accepted: October 29, 2018; Published: November 05, 2018

*Corresponding author: Bernard TROUDE, Associate Researcher of CEAQ Paris/Montpellier (Centre d'études de l'actuel et du Quotidien), Correspondent/Associate Researcher of International Academy of Medical Ethics (Académie Internationale d'Éthique Médicale), Correspondent / Researcher of Sffem /Elsevier-Masson, Paris. E-mail: bernard.troude@wanadoo.fr

\begin{abstract}
Surrogate Mother, Procreate for Others

Involved are heterosexual parents, single mothers or fathers who are themselves heterosexual or homosexual. And one day, there will no longer be any question of surrogate motherhood: technical sciences and medical philosophy will have remedied the difficulties created by current morals.

Aware that we can only be dependent according to the text published also including the deletions of articles dedicated to human research. This is due to the many discrepancies and the texts on other provisions invoking responsibilities in bioethics and biomedicine (2012) including healthcare institutions and patients using these institutions. According to the law, which appears to be the leader of the game, it was a question of restoring to speech all the values of research, the value of dialogue between applicants, surrogate mothers and the medical society. This phenomenology, new in the course of social history, tends to be proven, despite very restrictive or even interdictive legislation; whereas we know that this situation is often the last resort to which couples or unattached individuals go. Another point of view is to point out that there cannot by nature be an essence of law that links the state to a certain conception of ethics in these areas.
\end{abstract}

Ethics in this area is to discourage anyone from intervening in substance while using formal consent on the desire to have a child.

The aim here is to prepare theories and their examples, concepts and expressions, efficient actions, and applicable protocols that can be used instead of the old models.

Keywords: FAM; LDC; Mother; Father; Surrogate mother; Single; Alone; Gestation; Suffering; Consolation; Words; Consent;

\section{Surrogate Mother, Procreate for Others (PMA)}

(PMA: Medically Assisted Reproduction) This involves heterosexual parents, single mothers or fathers who are themselves heterosexual or homosexual. And, better still, one day there will no longer be any question of surrogacy: technical sciences and medical philosophy having remedied the difficulties created by current morals. GPA is one of the medically assisted reproduction methods, prohibited in France and authorized in certain neighboring European countries. Sometimes we hear legally about Stipulation for Others. (stipulation for others: The stipulation for others is a legal expression used in the law of obligations designating an agreement by virtue of which a party, called promisor, undertakes towards a third party called beneficiary, to do or give something (or not to do something), and this thanks to the intervention of another party called stipulant. The originality comes from the fact that the third party beneficiary does not need to give his agreement to become a creditor of the promisor).

"To recognize a woman's control over her body" - even to carry another man's child [1].

Advocating for a very long time that every Being must have full and whole ownership of his body, I spoke out against any interference (state, religion or any other sectarianism or communitarianism) of individuals or social groups in the private life of anyone and thus in the private life of women. I refer to Ruwen Ogien and his opus Life, Death, the State while knowing that others think the opposite like Sylviane Agacinski for whom "Baby business is looking everywhere for bellies to rent. Propaganda for GS cannot mask the violence of such a practice... $[2,3]$ “.

The legislative debate of ideas being relaunched after the bioethics law of 2004 and its reassessment of 2010/2011 [4], although many people (including the Academy of Medicine and the geneticist A. Kahn) think that the legislator will have taken the position of the State Council on the fundamental condition of the (surrogate) mother, conditions which call into question the legal, social and anthropological prescriptions of any maternity. Aware that, we can only be suspicious, according to the text published, this also includes the deletions of articles dedicated to research on Man and his procreation because of the many divergences as well as texts on other provisions invoking the responsibilities in bioethics and biomedicine (2012) of health institutions and patients using these institutions, the preliminary at the end of the introduction clearly indicates: "... Indeed, during parliamentary debates, issues related to research involving the 
human person, including the supervision of prenatal diagnosis and the use of medically assisted procreation, were the subject of important discussions."

Are we not in the expansion of philosophical medicine? Or could we Re-understand the Living?

"When I was young, I had an astonishing passion for this science that we call 'Nature Inquiry"... To know the causes of each being, why each being is born, why it dies, (and before that) why it exists [5]

Thus, Platon disconcerted and angry by the death of Socrates reported the fact of Socrates' death, commented on it as a profound injustice marking him forever in his philosophy. It is at this moment about the trust put in the questioning word, in the verb that bothers and the possible objection. For the GS protocol, it is necessary to include this trust, this integrity and serenity, this word for an irreversibility of choice, in this word that consults and solicits while exposing situations with this intensity including the passion for truth without weariness and without consolation. Far be it from me not to assume that this questioning word could be suspicious, full of artifice and sneakiness. According to the law (see above), which can appear as a leader of the game, it is a question of restoring to speech all the values of research, the value of dialogue between the applicants, surrogate mothers and the medical society, society with a great $\mathrm{S}$. On the societal scene, I cannot neglect all those who do not speak out while being part of this community, this community (third party idea) for which any science (causal or correlative) cannot be the prerogative of a scientific or religious caste.

This phenomenon, quite new in the time of social history (initially the baby arriving without its recognized complete parenthoodis abastard) tends to be proven, despitevery restrictive or even interdicting legislation. While we know that this situation is often the last resort that couples or unattached individuals go to in order to obtain the desired parenting. Corollary difficulties, following a medical or genetic problem, or within the framework of a homosexual couples desiring a child, Gestation for Others (GPA) often appears as a legitimate and appropriate solution. For official morals, it is obvious that the concept is intolerable. Just as the right to die or to die must be "reformed", I explained to myself, this social subject becomes almost forbidden of transparency or simply of serious communication. All this under the guise of an apparent or not religiosity on the dogma: "One does not touch one's body..." Implied that a god created it (him) in his image E. Lévinas maintains that: "... ethics is not the corollary of the vision of a god, it is that of the vision itself..." [6].

If any legislation is to protect the body of (economically weak) Beings from any concupiscence and bargaining inclination (of the body or part of the body), a democracy must recognize its limits of power by law. No fear should be feared. Although faced with biomedical techniques, which for some time have posed unprecedented human problems, responsibilities without having to be diluted in a mass will be announced by excluding the continually repressive aspect of states and their laws. This would subsequently avoid possible disengagement of states in biomedical research and applications. On the other hand, my recurring question is whether a state system (public service) or a social system (religious) can retain the faculty to say, to prescribe, to compel the rational or usual method for any procreation or for any will to disappear. These facts being very often accompanied by dissuasions, impositions of method, intimidations then would it not be preferable (or better) to understand this task which would rather consist in protecting the conceptions of personal choices in each of these matters? In my speech you will hear my favor for these last points of view because any state could no longer make disappear by force (deontology) a conception of a particular ethics. Since it must defend religious pluralism under the protection of the law on secularism, the defense of the rights to moral pluralism must be practiced at the level of the state by all the means at its disposal: to protect each and everyone so that they are guaranteed the way of living according to deep moral convictions (spiritual or psychic or conformity to oneself), insofar as they would not cause manifest annoyance to others. E Levinas speaks of this "intersubjective relationship" which is a nonsymmetrical relationship; in the sense that we are responsible for others without expecting the reciprocal (Vrin, 1981). He spoke on the trans-affective basis of the moral relationship and the ethics of responsibility, an experience that gives us an understanding (hearing) of a deontology whose autonomy (independence) will be from the injunction of the descriptive rather than the prescriptive.

Self-fatigue is ordinary and collective where it would not be a particular form of our existence - our family, societal, home, business, and street environments - because they are common and overwhelming, because they are made of our sometimes vulgar and/or cruel surroundings. The weariness comes from the lack of forgetting oneself, forgetting in a form of weightlessness when existence demands innocence and especially emotion: this is the subject undertaken by these women and men (they in less part) to make appear a child in their life. This appearance avoids the installation of selfishness since the sharing and the gift of self intervene immediately when the free (I am not talking about the action that demands salary) and the gracious participate in the blossoming as a reminder of a commitment to exist and make exist, of all the firmness of an irrevocable contract. You have to produce something; you have to start and aspire to exist. This leitmotiv is an encouragement to compensate what Nature will have refused to any person since genetics (infertility of the person) or quite simply social by not having had the faculty to accomplish a union. Consent to find a solution requires voluntary choices of any device made available without having to undergo constraints from elsewhere or already restrictive before starting to think about.

Another point of view is to point out that there cannot by nature be an essence of law that would link the state to some conception of ethics in these areas. Consequently, only concrete legal systems exist in the more or less repressive liberal spirit: this is the choice made by several states whose tolerance is clearly expressed framing the practice of GS. Coincidentally, it was the same people who established this tolerance about all end-of- 
life (Belgium, Greece, England and U.K, Netherlands, Switzerland soon Spain and Italy, some states in the USA) I recall here, that only one criterion agrees to retain if such or such legal, penal instruction is more or less tolerant therefore non-directive: it is necessary to attribute this criterion when the most liberal legal system is it because it contains less "crimes without victims" (That is, sanctions against acts that cause harm only to oneself, to consenting adults or to abstract or symbolic things like gods, angels or the flag of the nation. At the time of the Enlightenment, the phrase "victimless crime" meant that blasphemy, sacrilege, suicide and sexual relations between consenting adults should be avoided.)

It is an answer for a society in which the spirit of the Enlightenment, the spirit of Paul Ricœur and Levinas would be maintained and preserved, while at the same time being Hippocratic speakers. To date, we would be able to classify GS in this concept of "crimes without victims", because it will be (become) unfair to sanction, repress, verbalize a conciliation, agreements between consenting persons who, as an initial principle, have no ambition to perpetrate harm vis-à-vis third parties; in any case, especially not to the child who will be born from this union of ideas. Paul Ricœur had this notion of classifying ideas in all matters: "In such a confrontation, my question will therefore be rather to know which questions come first, which others are simply derived, as soon as one poses an ethical problem. In this sense, I would prefer to speak of ethical intent " $[7,8]$

"Give in my mouth the true and estable word and fay of the middle language caulte ..." [9]

This being expressed, a bit of poetry: he reminds me of a premonitory song by Jean-Jacques Goldman: "Elle a fait un bébé tout seule" of which here is the chorus :

"She made a baby all by herself (bis) it was in those crazy years, when dads were no longer in fashion. She made a baby all by herself. (Bis) She chose the father as a scientist; for his genes, his astrological sign. She made a baby all by herself." (1987)

«Elle a fait un bébé toute seule (bis) C'était dans ces années un peu folles, Où les papas n'étaient plus à la mode Elle a fait un bébé toute seule (Bis) Elle a choisi le père en scientifique; Pour ses gènes, son signe astrologique. Elle a fait un bébé toute seule » (1987)

What do you think? First, that the father, out of fashion, is present only as a sire, as a "scientific" person. Let us admit that the status of men has evolved and is found in the same questions/ answers as our mirrors, women.

However, having a child on one's own is still generally associated with unmarried women (let us now add to a lesser extent: unmarried men) who, in the absence of a partner according to a choice or a non-choice, seek to become parents before it is really too late. The "too late" being in the medical and/ or social convention. However, some single men also want to become parents (dad), despite the absence of a partner. Becoming a single mother or father is often the fruit of a long and mature reflection, often generating psychological weariness because of this endless duration full of words. In most manifestations, access to parenthood is a journey full of misfortunes, adversity for a result, several years of research and expectations, a result that will be the child more than desired.

The involvement of the surrogate mother is to be pregnant during these 9 months for intended parents. The first option considered will be that the "father" will provide the genetic material (sperm) while also having the power to use egg donation. The logical sequence is handled by the medical team (After performing in vitro fertilization in a laboratory, the medical team transfers the embryo into the womb of the surrogate mother. Surrogacy, or GPA, is a medically assisted reproduction technique generally performed in cases of infertility, especially when the woman is sterile and cannot bear a child or become pregnant (for example in the absence or malformation of the uterus). Homosexual couples and single men can also use a surrogate mother to carry the child for them.) . But, let us know that: since the oocyte comes from another woman, the surrogate mother gives birth to a child that is not genetically hers. GS therefore allows this intended parent to become the child's biological father. The term "surrogate mother" or "gestational surrogacy" corresponds to a technique of Assisted Reproduction (AMP). AMP: a little less but just as controversial. The surrogate mother thus chosen receives the father's sperm or an embryo already fertilized according to the parents' wishes. This process of gestational surrogacy becomes clearly more complicated as soon as one takes a closer look at the legislation in force... Several options are available to women or men seeking to have a child alone: adoption, co-parenting and gestational surrogacy (GPA).

"What I'm trying to translate for you is more mysterious, tangled at the very roots of being, at the impalpable source of sensations "[10].

If I do not have to make a decision as to the formalism and corporatist spirit of which the official government documents themselves state to denounce them, I have listened to the supporters of the "two shores" who interest us only for their common essence: source of difficulties which they have the ones and the others with their words and especially when it is a question of the GPA. It is clear that the incommunicability of the motives advanced (for or against), if it can support a lecture course does not go hand in hand with the mastery of the protagonists, of which there should be no doubt, that at least with a teaching assigned to the subject during requiring a particular pedagogy. We can see this when it was necessary in the past (as early as 1974 -IVG- then 1994 and as early as 2012 - Ethics -) to make at least one instructive lecture for the form in front of some qualified others. This is why my eternally reaffirmed attachment to the same edge of bias taken for the traditional technique of assisted procreation after having made an assessment of the tests at the frontier fields (Lacanian terms) above assumed cannot progress without uncertainty: for the GPA, this is measured by the substitution of the term of traditional for that of orthodox to qualify this technique of procreation. Both are related to convenience for want of knowing how to say nothing about the precept or postulate of authorizing nothing. 
Nevertheless, in France, GS remains prohibited because it is considered as a form of exploitation and commercialization of women's bodies. If there cannot be an exclusive right that is founded, it cannot be a question of these people earning a living given the apparent misery in which they may find themselves. On the other hand, how to deny a right to those who would be in need, the right to consent to many things thus renouncing their physical (otherwise harmed by the economy from which they suffer) or even moral (each, each claiming to possess his or her own morals instilled and/or learned). As for selling some of the organs if NOTHING prevents them, why ban? There are other elements to prohibit such as sleep markets before those that are the full and entire property of the person. I repeat and maintain. To disregard the opinion of the person on the pretext that he is not freely informed, sufficiently determined in his choices or rationality is not as essential as it may appear is a fault. It thus requires thinking that all these phenomenologies may not be in concordance with the current society but that in no case would it require a justification to be able to claim an authority of democracy. Can situations of domination be judged by renouncing consent as a criterion of justice in person-to-person relationships? No middleman? I wonder about the college that would be able and empowered to decide if such or such person can be in a state of inferiority, a state of dignity or a state of understanding information: sociologists, health practitioners, metaphysicist, and philosophers? To exclude the person, the persons whose consent is tacit will cause notorious harm and would amount to treating the subjects in a paternalistic, condescending, even humiliating manner.

Ethics in this matter is to dissuade anyone from intervening in this matter while using formal consent to exculpate him from a dominant to dominated relationship: undeniable injustice. This prohibition pushes parents of intention and many couples (single men or single women) to go abroad to form a family (Forming a family: my preference is for these terms rather than "HAVING a child". The verb" to have" denotes a concept of absolute property when we know it well: no child belongs to his parents. From conception, it is free even if it is dominated, abused or over preserved. (F. Dolto)) by GPA (often in the United Kingdom, Belgium, the United States or Canada). Françoise Dolto explained and convinced many of those who approached and listened to her. She stated (already) that: "The child was neither a simple 'object' of care, nor a miniature adult, but really a whole person. From her original practice of listening to the little ones, she has acquired the certainty that, however young he may be, the child is a human being, a desiring subject, someone to talk to and, above all, someone who answers you in his own way! "Following in the footsteps of Donald Winnicott, who first stated that "the child is a person", [11] Françoise Dolto's discovery changed the way she looked at the little man. Making it even easier psychologically to "fulfill" a desire for a child. Moreover, it is still complicated, today in France, to obtain recognition for children born abroad with a French father and a surrogate mother.

These are the difficulties that future single parents must go through.
"If one could possess, seize and know the other, he would not be the other. To possess, to know, to grasp are synonyms of power. "[12]

Our research in biology, embryology and human reproductive materials is all full of gradations while we do not see exactly how each of the levels differs from what conventional research called order or totality, but no question had arisen that could not (should not) be. Much contested by a group opposed to all research, this approach to FAM and surrogacy promises that a solution can be considered. The real question will be: are surrogate mothers free or are they exploited? Again, this is a very personal consensus and no one (good or evil) has the right to oppose it for exactly the same reasons as those who oppose this reproductive process. All the liberal visions advocated by all project leaders against GS or PMA (there is obviously a distinction to be made here) are the same as the ideas included in the permission and the right to the child. It is imperative to let people live, as they want, freely. Should we distinguish between "rights of" and "rights to"? Are we in a society that is more and more permissive for certain ways of living, forgetting to include in individual freedoms the right to property of the body, the right to come and express oneself, to live a sexual life at one's convenience and to want to live with children, the right to stop living, the right not to take care of oneself. In short, the right to live according to one's will and to act without being prevented by anyone or anything. It is not by putting "rights to" forward that can imply demands creating a "duty to" (in others)

In a work done in the street [13], I have in no way contested that the right to life can force us to feed (children or adults), society having largely rid itself of solidarity for those who depend on us, to help someone who is in danger. I do not mention here all the work done by eminent actors of the society of the Health and Social Emergencies. Our obligations towards others are not reproducible by others towards us. This system of rights should call for common assistance in addition to that of the state through its institutions, which cannot be immediate. The difference with ultra-liberals or simply liberals is that they do not understand this right to the child and include this right in a democratic and certainly therapeutic vision. The right to the child, while it may be organic in a person, may just as well exist as psychological therapy for one person or another. This supports the right to assistance without being able to demand a right to find a partner (sexual or marital) or to seek offspring.

The gradation I have raised is a "net thrown into the sea" without being able to predict what will come up. This freedom of action is about to overcome many vain dilemmas, provided that communications are made from time to time on specific points. For example: Why does the M.O. work for some and may fail for others? In short, can ABM be a science that is understood with a proven success rate? May it see itself as a construction on the basis of a raw or existing world; a world that opposes laudable claims while knowing that they are not operating modes blind to the constitutive value that "the concepts of Nature could have in an idealistic philosophy [14] or medical philosophy. 
These are still topical questions that constantly arise and merge in our democracies, which are in rather bad shape. The process is part of the subject here: imaginary and religious utopias govern sensibilities. I say that a (direct) word, a gesture with empathy should suffice. Moreover, knowing how to console someone whose activity is difficult implies taking the floor to denounce the sufferings that we cannot all share to the same degree. But in which (suffering) we can seek to take part. This is a concept close to the free solidarity that many populations of which those of Switzerland or Anglo-Saxon (Canada is apart) are completely foreign. How can we not betray by trying to find our way into the intimacy of others? In fundamental ethics (if that can be conceived), which words, which verbs, which expressions to use avoiding the seed of suspicion? Some will admit these questions for a psychological concept while others (more sectarian) will see there a religious basis. Almost immediately are brought closer to glimpses such as the political context (an end to ideologies and a form of seduction by long-term technical solutions), the projection in one before of institutions that are part of the duration of their representations and their applications, the imaginary or the utopia of a better future. I return to Paul Ricœur who said: we are all in the fact that we are under "the constant pressure that the moral (of the moment) of conviction exerts on the moral of responsibility". It is true that in this time of controversies, of low democratic waters (said in 2003) and of the expansion of populisms, this reminder made by the philosopher of any political action and their reasons can only be useful but absolutely necessary [15].

\section{Technical Sciences and Medical Philosophy}

We are still at the point where it is necessary and unavoidable that a child begins his life with the space of the female belly. However, there are serious advances in medical research on the subject of the "hybrid" or "plastic" placental pouch, the latter terms being used to designate a new materialology in relation to tissues and other necessary human elements.

Somewhere, is there a research movement to avoid this "natural obligation" trap of creation? Why not think about getting around that diktat? Perhaps we should take a global interest in the equalization of LIVING, which one-day will have to be integrated into research methods in biology and bioethics? I feel other implications to these questions. Involvement of the model in knowing which interactions (between 'materials') would have an essential aspect in biological processes. But again: Which interactions would have a preponderant involvement in a formation of macromolecular arrangements whether in marking, rationalization and (perhaps?) control for the apparent axes of any metabolism. Defining a high specificity of such interactions will make them ideal objectives for knowing therapeutic agents, for determining the functions of certain unknown elements (critical research space). These are questions that I formulate when in nothing can I claim to be a doctor/researcher but as an advanced researcher in any health ethics system I can ask myself. Even if it is true that the inconveniences known to "surrogate mothers" may seem to be an epiphenomenon of the situation. This being the awareness of having a desired child and being a "future single parent" is too recent to draw a hasty conclusion on the proportion of unwelcome hazards in relation to the majority of FAM or LDC cases.

My idea is moving towards a "placental robot/pocket" or "non-human body pocket". In fact, having a fertilization and an implantation outside the human body supposes that many questions would be solved since there would no longer be any question; while knowing that other questions will arise without the contexts and the dispositions being known in advance, questions which see the concepts of economy and "markets" emerging. This gestational surrogacy, or GS, is a reproductive technique; especially when the woman is sterile and cannot bear a child or "become pregnant" (for example in the absence or malformation of the uterus). Homosexual couples and single men are also affected by the use of a surrogate mother who will carry the child for them. (Other solutions for single people exist, including becoming a parent through co-parenting. While co-parenting is especially popular among LGBTQ couples and single women, more and more single men are also interested. it is possible to meet men and women who want to become fathers or mothers thanks to co-parenting. The two (or more) co-parents decide to share parental authority and to look after the child's upbringing jointly, the child's best interests and well-being being their priority) In all these cases, there is an interpersonal relationship that determines that it is not a question of thinking together, the other and me but of being in front of each other with the elaboration of consent. It happens that we find ourselves in a true union whereas the true whole can only be a whole of synthesis, but a face to face. Synthesis set and then why not determines for a research device, that it would no longer be necessary to have a human belly to obtain the birth of a child. Francis Wolff [16] describes his resentment by this title of opus "there is no perfect love", I make follow by: "There is no happy love" [17] is the same theme described by L. Aragon and set to music by G. Brassens.

Since the child would no longer be for these people a "fruit of love" between two people who have chosen each other for body, mind and sexual accommodation, let us ignore this two-for-one conception. A single person (convinced) can pass on his or her message of wanting a child even before he or she knows how to choose a partner because choosing a partner is of no primary interest to his or her understanding. And the child you say to me? The child will be like thousands whose number is growing alone without a real family, in a reconstituted family, in a family destroyed by wars, famines, epidemics and social events (divorce, murder, abuse, etc.) that adults are capable of generating. However, there is nothing to prevent future parents from being told that they must know how to communicate, must develop their ability to communicate effectively, efficiently and sensitively with their child and their environment for their child. One day or the other this question will be asked even if with the detractors and their morals, science can go in the same direction.

For the moment!

This is the time that these parents of intent. 
It is important not to venture and to choose THE GOOD PERSON (he or she) who will appear as "ideal" for consent, which corresponds to the parental project by having the same objectives and values, who will share the same desire for the child. Let's admit that if SCIENCE could remedy and supplement the belly! Today, these questions stem from psychology and morality (religious conviction). However, a return to philosophy, which for a long time has been a quintessence for human worries, the sufferings said and not said, seems to once again become with reason as a possibility of consolation. This consolation (consoling will) from Plato, the Stoics manifests itself as a social act mobilizing language, speech and the verb, says something to our human condition. In his search to found a family (there must be a child, this desire for a child) the consolation does not in any case resolve the suffering of the lack, the suffering of the failed act. Michaël Fœssel indicates that this responds to the "suffering of suffering" which is loneliness, shame or guilt. Each individual in this child shortage is comforted by an interview possibility. Philosophy (medical or psychological philosophy) "often interprets as narcotics the means used by the comforter to alleviate the suffering of others. It also sometimes incriminates the need to be comforted. Fœssel quotes Hans Blumenberg, the contemporary philosopher, who takes consolation seriously: every consolation is an "avoidance of conscience" [18]. The subject (man or woman) hopes to no longer see what he is separated from (because of freedom of choice): happiness, justice and, above all, truth. Every comforter (whether for or against decisions made by others) learns to live beyond the point where it seems impossible [19].

\section{Let Us Finish this Presentation}

The body defeats science, knowledge; therefore, we must remember that this knowledge can be found in the way that the soul is freed from the body. Let us hope (hopefully) that SCIENCE, the hard technical sciences and the soft human sciences together, will open the procreation sector out of the body. However, the acquisition of any science involves intermediate steps, the acquisition by GS requires a science of the idea from the sensitive to the idea as we do not go directly from an embarrassed assessment of subjectivity to intuitive discernment. It requires preparatory language, healthy and objective communication, and confidence in oneself and in others. Hard acquisition of the idea itself. Will the body and the brain facilitate this acquisition? The body is still and for a long time a set of sensory organs. It is an intellectual claim of the body that often preoccupies social groups that I can speak out against. I am neither the first nor the last; Platon in "Phædon" reports this idea [20].

\section{Stimulating Knowledge and Action}

"In an indefinite movement of latent reason with manifest reason and in an indefinite effort to govern itself through that human truth and authenticity which are its own - if all this is merely the historical fact of an illusion, (...) Philosophy, science would then be the historical movement of revelation of universal reason, "innate" to humanity as such (...) Thus the essence of man is not GIVEN, nor its need for unconditional essence [21]." So we can hope to transgress including for creation and procreation.
Another requirement is then added, which is morality and freedom to act. All freedom entails the rights of the other and the rights of the (Western) "I" accuse a right of reciprocity of the "You" which becomes this natural right and demands the autonomy of being. Levinas in his opus [22] asks that not the thought of the same but that of the other be put forward as an ethical action and as the primary philosophy of action: the other has his right to prescribe his actions whatever they may be.

Another question about this "transformation of the reproductive environment": will we have all the truths by mixing all the senses? Nevertheless, all information may be discussed, challenged or simply discarded. To apprehend the idea is to apprehend reality, whereas we must aspire to reality by applying ourselves to the art of reasoning, so that nothing can disturb the flow of the concept. Socrates reported by Platon indicates "The body which is a sensitive reality - and does not cease to change - is by definition foreign to the Idea which is eternal. For any change, even if it is real and ongoing in and by society, which uses this different functioning of a historical context or the same context can only know the same, it must be agreed that the agitation of this change involves some practical problems. It will be necessary that opponents to any change stop complaining in the World of Shadows and in verbal entertainment. It is important to revoke the senses (morals or transmitted values) that relate to the sensitive world and finally not be affected by pain and bodily pleasures that preoccupy the senses and the essence of known values. Indeed, any real or psychosomatic pain is a summation to our brains by a body that is experiencing a difficulty. The parents of intention are well confronted with this summons in their body, their mind.

This set should be a general culture module (there are so many opponents) and have a motivated and/or qualified teaching of medical ethics in procreation. Already cited by B. Hœrni [23] in his opus: "in almost no teaching, next to rare structured initiatives... training begins artisanal and empirical and when they exist: "we have received no teaching (substantive) no training (psychological) no opening (philosophical)... in relation to the other, his body, death and the act of healing." Let us open the doors to all challenges due to a lack of clarity and reasoning on issues of concern in a changing society. The point here is to prepare theories and their examples, concepts and their expressions, efficient actions, applicable protocols that are needed instead of the old models.

Including for the subjects covered here

\section{References}

1. Sylviane Agacinski, Sylviane Agacinski, Ruwen Ogien. Carrying mothers: free or exploited? Forum Expat. 2009.

2. Ruwen Ogien. Life, Death, the State (La Vie, la Mort, l'Etat,) Paris. Publisher Grasset. 2009.

3. Sylviane Agacinski. Body shredded (Corps en miettes), Paris, publisher Flammarion, coll. Café Voltaire. 2013.

4. The law (n²011-814) of 7 July 2011 relating to bioethics adapts the texts in force to developments in science and research, without call- 
ing into question the fundamental principles of bioethics - that are the dignity of the human being, the respect due to the body, the protection of the embryo, anonymity, free donation, the free and informed nature of consent.

5. PLATON, Phédon, traduct. Monique Dixaut, Paris, publisher Flammarion, coll. Poche, Philosophie. 1999.

6. Emmanuel LEVINAS. Difficult Liberty (Difficile Liberté), (1963) Paris, publisher Albin Michel, 4ème édition, coll. Presence of Judaism. 1996.

7. Emmanuel LEVINAS. Ethics and Infinity (Éthique et Infini), Interviews with Ph. Nemo France/Culture (1981/1982), Paris, publisher Le Livre de Poche, coll. Biblio Essais. 1984.

8. Paul RICOEUR. Basis of ethics, Lecture by the author to the Protestant Center of the West during a session on "Ethics and Politics" in July 1983 in Cahiers du CPO, n²49/50. 1983.

9. Jacques LACAN. Function and field of speech and language, L'Internele Consolacion, XLVe chapter: that not everyone should believe and of the slight stumbling of words. Paris, in La Psychanalyse, n 1, P.U.F. 1956. url consulted:

10. http://staferla.free.fr/Lacan/Fonction\%20et\%20champ.pdf

11. Joachim GASQUET, CÉZANNE, (1921) Paris, publishercEncre Marine, coll: Hors collection. 2003.

12. Françoise DOLTO, The Child like No One, url consulted on 10/01/2018 in Journal La Croix, 04/11/2008.

13. https://www.la-croix.com/pdf/http://www.la-croix.com/Famille/ Parents-Enfants/Dossiers/Education-et-Valeurs/Donner-desreperes/Francoise-Dolto-a-su-reveler-la-grandeur-de-l-enfant-_NP_2008-11-04-540844

14. Emmanuel LEVINAS. Time and the other (Le temps et l'autre), Paris, Publisher PUF, coll. Quadrige. 1983.
15. Bernard TROUDE. Five Momentary Street Immersions, and Vision of a society around a holographic IGH: between Kafka, Trin Xuan Thuan and all the others (Cinq Immersions Momentanées dans la rue, Vision d'une société autour d'un IGH holographique: entre Kafka, Trin Xuan Thuan et tous les autres). Paris, Publisher Édilivre. 2017.

16. Maurice MERLEAU-PONTY. The Eye and Mind (L'œEil et l'esprit), Paris, Publisher Folio, coll ; Folio-Essais, Chapitre I. 1985.

17. Paul RICœUR. Philosophy, ethics and politics, Interviews and dialogues (Philosophie, éthique et politique, Entretiens et dialogues), (1981/2003) Paris, publisher SEUIL, coll. Couleur Idées, Chapitre 1. 2017.

18. Francis WOLFF. There is no perfect love (Il n'y a pas d'amour parfait), Paris, Publisher Fayard, coll. Histoire de la pensée. 2016.

19. Louis ARAGON. (1943/1944) there is no happy love, Poem, (Il n'y a pas d'amour heureux) published in 1946 set to music by Georges Brassens, 1950 and covered in 1967 by Françoise Hardy.

20. Hans BLUMENBERG. Description of the man (Description de l'homme), (2006) trad. Denis Trierweller, Paris, Publisher du Cerf. 2011:585.

21. Michaël FOESSEL. The Time of consolation (Le Temps de la consolation), Paris, Publisher The SEUIL, coll. L'ordre Philosophique, 2015

22. PLATON, Phaédon, ibid.

23. Maurice MERLEAU-PONTY. Signs, § Philosophy and sociology (Signes, $\S$ La philosophie et la sociologie), (1960) Paris, publisher Gallimard, coll. Folio Essais. 2001:180.

24.Emmanuel LEVINAS. Difficult liberty (Difficile liberté), (1963), Ibid. 1996.

25. Bernard HOERNI. Medical Ethics and Professional Conduct (Éthique et déontologie en médecine), Paris, Publisher Glyphe, coll. Society, History and Medicine. 2015:238. 